\title{
CSR, Sustainable Value Creation and Shareholder Relations*
}

\author{
Daniela M. Salvioni ${ }^{* *}$, Francesca Gennari ${ }^{* * *}$
}

\begin{abstract}
The establishment of integrated corporate social responsibility principles, the growing complexity and importance of business/stakeholder relationships, and the elimination of space and time barriers to the circulation of information and capital change the corporate governance approach of listed companies. This situation attenuates the business approach, which has characterised firms with wide ownership dispersion (outsider systems) and those with concentrated ownership or control (insider systems) for a long time. This discussion article aims to be a theoretical contribution, which investigates the relationship between integrated CSR and investors according to a management model able to create sustainable value and optimise meeting the interests of shareholders and other stakeholders. Corporate social responsibility and an orientation towards sustainability facilitate the reduction of business risk and the creation of value in the medium-to long-term, regardless of the ownership structure of companies and the characteristics of risk capital markets.
\end{abstract}

Keywords: Integrated Corporate Social Responsibility; Corporate Governance; Value Creation; Stakeholder Engagement; Investor Relations; Shareholder Value

\section{Integrated CSR as a Governance Driver}

The assertion of concepts such as corporate social responsibility (CSR) and sustainability, together with the valorisation of the stakeholder perspective (Freeman et al., 2010; Harrison et al., 2015; Schaltegger et al., 2017) have affirmed a new approach to the role of companies in society. Sustainability is a long-term vision that characterizes socially responsible companies and that refers to a concept of global responsibility including economic, social and environmental aspects (Carroll, 1999; Van Marrewijk \& Were, 2003; Aras \& Crowter, 2008; Dahlsrud, 2008). In this regard, the effectiveness of governance for the development of company in the longterm, maximizing the creation of value and minimizing the risks is significantly influenced by the adoption of policies that emphasise the principles of integrated social responsibility, positive and equal interaction with stakeholders, and respect for the environment (Salvioni \& Astori, 2013).

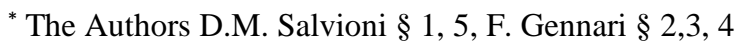

${ }^{* *}$ Full Professor of Business Administration, University of Brescia (daniela.salvioni@unibs.it)

*** Associate Professor of Business Administration, University of Brescia (francesca.gennari@unibs.it)
} 
Globalisation and the emergence of the concept of integrated corporate social responsibility have undoubtedly underlined the need for greater convergence between corporate governance systems, the limitations of over-focusing on the shareholder view, and the change in variables that influence the attraction of capital.

Since the beginning of this century, attention to the corporate governance of public interest companies has grown, particularly with regard to the ability to activate an ever-wider and more complex network of relationships. The latter are correlated, on the one hand, to the need to achieve positive, lasting relationships with all relevant stakeholders and the importance of a competitive orientation towards the market with regard to all trading areas. On the other hand, the network of relations focuses on the effectiveness, flexibility, and convergence of corporate governance principles in the various national realities increasing the opportunities for competition and benchmarking among firms.

The globalisation of markets and information (Brondoni, 2014) has led to growing competition among companies to obtain approval and resources from significant stakeholders, changing the premises for corporate success, which depends on the capability to create shared value (Porter \& Kramer, 2006; Porter \& Kramer, 2011). Implementing strategies oriented towards shared value implies creating economic value in a way that also creates value for society (Lambin, 2014): the competitiveness of companies increases due to the economic, social and environmental dimensions that nurture each other and strengthen the relationships between the company and its stakeholders. This approach modifies the board's attitude towards shareholders, promoting the maximisation of economic performance in the long rather than short term.

Shareholders have always had a significant role in conferring the mandate of corporate governance. This has contributed, on the one hand, to affirming the shareholder view, which dominated the orientation of corporate governance for a long time, emphasising economic performance and financial reporting and, on the other hand, to producing divergences in governance relating to the ownership structure and stock market characteristics.

Nowadays, after the scandals and financial crises of recent decades, a fundamental idea is shared: creating shareholder value is not the same as maximising short-term profits. Companies that confuse the two often put both shareholder value and stakeholder interests at risk (Goedhart et al., 2015). The creation of shareholder value is not in contrast with the satisfaction of other key stakeholders' interests; the real problem is the excessive short-termism that characterises short-sighted boards, often related to the relationship between the firm's owners and those developing its management processes.

\footnotetext{
$\square$ "Companies have begun to devote greater attention to these issues of long-term sustainability, but despite increased rhetorical commitment, they have continued to engage in buybacks at a furious pace. In fact, for the 12 months ending in the third quarter of 2016, the value of dividends and buybacks by S\&P 500 companies exceeded those companies' operating profit" (Letter from Larry Fink, CEO of BlackRock to chief executives at $S \& P 500$ companies and large European corporations, https://www.blackrock.com/corporate/en-us/investor-relations/larry-finkceo-letter)
} 
Those words point out that a company's priorities for investing for long-term growth need the conviction of its management. The return of capital to shareholders should be supported, but companies must balance those practices with investment in future growth, being confident on the long-term returns of investing in future growth. This attention and commitment by management for future is assessed by stakeholders that decide or not to confirm their consent toward company.

The valorisation of CSR and the importance of the stakeholder view do not imply a loss in adequate returns on risk capital; conversely, they emphasise the interdependence between the management of stakeholder relationships, economic, social and environmental responsibility, economic and non-economic results, and the ability to obtain consensus and resources. This affirms a governance approach aimed at promoting the creation of shareholder value over time, balancing the natural tradeoffs among the interests of different stakeholders that could be apparently at odds with one another (Goedhart et al., 2015). When trade-offs exist the CSR approach suggests prioritising long-term sustainable value creation as fundamental for the company's future life and success and this longer-term approach will also be reflected in the type of investors (Eccles et al., 2014).

\begin{abstract}
$\square$ In 2011, the European Union Commission affirmed: "A strategic approach to CSR is increasingly important to the competitiveness of enterprises. It can bring benefits in terms of risk management, cost savings, access to capital, customer relationships, human resource management, and innovation capacity. Because CSR requires engagement with internal and external stakeholders, it enables enterprises to better anticipate and take advantage of fast changing societal expectations and operating conditions. It can therefore drive the development of new markets and create opportunities for growth. By addressing their social responsibility, enterprises can build long-term employee, consumer and citizen trust as a basis for sustainable business models. Higher levels of trust in turn help to create an environment in which enterprises can innovate and grow". (European Commission, 2011, Communication from the Commission to the European Parliament, the Council, the European Economic and Social Committee and the Committee of the Regions. A Renewed EU Strategy 2011-14 for Corporate Social Responsibility)
\end{abstract}

The companies' ability to understand the potential benefits of adopting a socially responsible strategy and create and manage relations with their stakeholders changes the relevant performance evaluation dimensions and timing guidance on value creation. Therefore, corporate strategy promotes and disseminates values and principles that generate behaviours that are fundamental for sustainable value creation (Salvioni et al., 2014).

CSR is increasingly becoming a driver of business because it makes business sustainable and creates value for shareholders and other stakeholders, promoting consensus concerning the corporate project. CSR is one of the business competition levers that attract consumers and investors, who are increasingly aware and willing to reward companies oriented towards the creation of sustainable value. 
The management of stakeholder relationships becomes a source of competitive advantage in globalised and dynamic capital markets (Hillman \& Keim, 2001; Brondoni, 2003; Salvioni \& Gennari, 2016) and sustainable value creation increases the capacity for consensus and attraction of resources.

The effectiveness of such relations with stakeholders depends both on the company's enhancement of connections among economic, competitive and socioenvironmental variables to be included in the strategies, according to an integrated design, and on the company's systems of accountability and transparent communication for generating consensus and collaborative responses from stakeholders (Bosetti, 2015). The adoption of an integrated CSR approach implies responsible corporate governance that modifies the governance variables and key performance indicators (KPIs). This situation also promotes convergence conditions that transcend the traditional differences in corporate governance systems due to the ownership structure and stock market characteristics (Salvioni \& Gennari, 2014; Salvioni et al. (a), 2016).

The characteristics of financial markets and the level of concentration of corporate ownership are the main differentiating elements in the governance approach of listed firms. In this respect, outsider systems are distinguished from insider ones. Outsider systems, typical of Anglo-Saxon countries, are characterised by the dominance of large publicly traded firms, fractional and dispersed ownership, and ownership and management separation. Poorly developed financial markets, concentrated and commonly stable shareholding, and majority shareholders' involvement in management such as to influence corporate decisions characterise insider systems, typical of many European countries.

For a long time, the dominance of the shareholder view and the overwhelming emphasis on economic responsibility have determined a different temporal orientation in the value creation of outsider and insider corporate governance systems. A governance model based on integrated CSR presupposes a corporate stakeholder network based on a strong positive correlation between the assumption of socially responsible behaviour and long-term shareholder returns. Therefore, when a board of directors redefines corporate priorities and goals according to the principles of integrated CSR, it tends to overcome some traditional structural differences between outsider and insider corporate governance systems and to promote convergence pathways.

\section{Sustainable Value Creation}

Globalisation is particularly significant in the capital market, since the transition to electronic monetisation and the fall of barriers to information transfer enable the simultaneous satisfaction of planetary demand and supply of corporate shares. The establishment of effective relationships with shareholders, according to a CSR approach, is based on the company and investors' capability to maximise future value even at the expense of lower short-term earnings. This means seeking out measures of performance linked to a credible and shared long-term business strategy (CVSG, 2007).

Scholars (Winston \& Patterson, 2006; Tonello, 2010; NACD, 2014; Salvioni et al. (b), 2016) and international guidelines suggest the active commitment of the board 
as the factor that truly influences the corporate approach toward social responsibility and sustainability by means of the definition of corporate strategies and related indicators. Consequently, the elements that take on greater importance include promoting the integrity of the corporate governance management function accompanied by national and supranational initiatives, aimed at reducing the gap between global markets and the divergences in corporate governance systems, and external supervision characterising different countries.

The globalisation of information and the emergence of a broad concept of responsibility have significantly influenced the evolution of corporate governance. Specifically, the partiality and limits inherent to the lack of correlation between meeting shareholder expectations and the overall effectiveness of the firm's market relationships, and the need for greater corporate governance convergence based on structural and operational best practices serve to ensure adequate and widespread attraction of consensus and resources.

The potential to optimise results over time depends on the appreciation of the expectations of all stakeholders with whom the firm interacts. Activating positive stakeholder engagement processes has increasingly become a prerequisite for the development of virtuous circles among resources, activities, achievements and consensus with a view to the risk factors influencing firm operations and the increasing complexity of direct and mediated relationships between firms and markets.

Strategic values of economic, social, and environmental responsibility integration, the internal diffusion and sharing of sustainability-oriented values and principles, and the set-up of integrated and complete risk management systems significantly influence the optimisation of corporate potential in terms of sustainable value creation, and the introduction of operative procedures designed with an awareness of the risk related to possible violations in the firm's operational activities.

Impetus from the board favours the implementation of sustainable practices in the organisation and creates a sustainability culture that goes beyond the mandatory rules and outside pressures, becoming a corporate intangible asset, a source of competitive success (Brondoni, 2010; Salvioni, 2010). Therefore, boards should define metrics of long-term value creation considering the firm-specific issues connected with the long-term value, the existence of many types of investors whose interests must be balanced, and the best practices in use, de-emphasizing short-term financial metrics (CVSG, 2007).

Strategies oriented towards integrated CSR are clearly aware of the responsibilities towards different stakeholders and they adopt methods and tools of governance aimed at improving economic, social, and green/ecological performance. In these processes, sustainable goals and objectives consider a new type of value generated by risk reduction and exploitation of opportunities, thanks to the constant and bidirectional relations with stakeholders (stakeholder engagement). Specifically, the board should constantly weight both long-term and short-term use of capital, determining the appropriate allocation of resources in relation to the threedimensionality of business responsibilities.

The maintenance of a satisfactory level of effectiveness requires the assessment of stakeholders' expectations and environmental impact and their alignment with corporate strategies, the transfer of the top management orientation in business 
conduct, and the verification of coherence between managerial objectives and actual results, optimizing the performances and relations.

In the above field, the firm's expertise and innovation capacity are increasingly important for maintaining the conditions of success, coupled with the assertion of effective principles of responsible business conduct (RBC).

The potential for creating sustainable value stands on two pillars: the quality of corporate governance decisions through an integrated approach to responsibility and the ability to transfer the sustainability objectives derived from the socially responsible strategy into the behaviours of the entire organisation.

The translation of sustainable goals into actual results gives importance to the internal communication system in order to connect the behavioural effectiveness of the organisation to the multidimensionality of performance across the triple bottom line. In particular, starting from a vision of governance inspired by shareholders and stakeholders' engagement, the development of internal control systems should assure the achievement and monitoring of CSR goals. The CSR approach implies the progressive use of socio-environmental indicators, together with the acknowledgement of the critical role of intangible components such as organisational capital, human capital and relational capital (Salvioni et al. (b), 2016). Therefore, the adoption of a CSR approach to governance requires the redesign of internal control systems, considering the changes to the key success performance indicators.

\section{CSR and Shareholder Relations}

The internal dimension of integrated corporate social responsibility complements the external dimension, associated with relationships with all stakeholders who do not directly intervene in management. The shareholders play a primary role in this context.

Shareholder engagement is a critical corporate governance issue, also stressed by international initiatives: some investors may seek a voice in the company's strategy definition and decision-making, recognising that this type of empowerment necessarily involves the assumption of a degree of responsibility in the achievement of such goals (Business Roundtable, 2016). This empowerment of shareholders in board decision-making should improve the company's capital allocation process and strategy to find the right balance between short-term results requirement and longterm value creation.

$\square$ “Our funds typically hold companies' stock for long periods of time, and in the case of index funds, we are near-permanent investors. We believe good corporate governance is key to helping these companies maximize returns over time, and we view effective management of environmental and social risks as an integrated component of good corporate governance practices. Significant analysis and effort are put into discussions with the directors and managers of the companies in which we invest; the level and frequency of these discussions may be influenced by the material impact to our funds and the contentiousness of the issue. We believe these engagements, more so than voting, provide 


\author{
an opportunity to fully understand issues and target feedback and \\ messaging to companies." \\ (Source: https:// vanguard.com/investment-stewardship/policies-and- \\ guidelines)
}

An ongoing dialogue between a company and its shareholders is a critical factor for maintaining effective investor relations and it should be implemented by means of standardised processes and mechanisms. This situation implies that the board's decisions are taken under a clear point of view that is not influenced by short-term pressures, in the interest of various types of shareholders. The board's orientation towards the long-term can increase when the executives' remuneration is based on long-term performance. In the same way, institutional investors should also ensure that performance measures and compensation policies for their executives and investment managers emphasise long-term value creation, considering this as a relevant factor for investment risk reduction (CVSG, 2007). For listed firms the relevance of a competitive capital orientation is evident. This is because the capital market is a primary source of resources and consequently the role of the demand/supply of capital shares is a tool to assert the firm's value and to demonstrate consensus on the activities of the governance bodies, due to the increasingly frequent need to counteract and/or mitigate the effects of speculative behaviours.

The adoption of corporate strategies embedded in integrated social responsibility responds to the pursuit of competitive advantage in global markets, increasing firm value and maintaining appropriate stock enhancement capabilities. For this reason, it tends to qualify as a best practice, promoting a substantial convergence worldwide that goes beyond the traditional differences in corporate governance structures due to ownership and capital markets characteristics (Salvioni \& Gennari, 2014).

For a long time, the high dispersion of share capital and the short governance mandates typical of outsider systems have determined the frequent correlation between business success and short-term profit maximisation. In such contexts, shareholders tend to evaluate the effectiveness of governance with respect to expectations of short-term return and their consensus is reflected in renewing the mandates of the board members and in the market value of shares. Conversely, in insider systems, the high concentration of capital and the frequent involvement of majority shareholders in management, often with executive roles, tended to be reflected in the governance approach towards maximising potential for value creation over time. With the assertion of effective RBC principles, this divergence progressively attenuates, favouring better circulation of capital and the crossing of speculative investment logics that are often characterised by a high shareholders' turnover.

The tendency towards the creation of long-term value stresses the efficacy of corporate governance and contributes to creating stable relations with shareholders. Furthermore, it gets the effectiveness of external control actions (information certification and controls activated by stock markets and specific institutions) involved in guaranteeing the transparency of behaviours associated with clear, verifiable and truthful communications able to meet the cognitive and evaluative expectations of existing and potential investors.

Finally, it seems appropriate to highlight the assertion of the Environmental, Social and Governance (ESG) criteria, which refers to the three central factors in measuring the sustainability and ethical impact of an investment in a company. The development 
of ESG factors for investment analysis has progressively spread, together with the importance of the creation of sustainable value.

\begin{abstract}
$\square$ In September 2017 MSCI Inc., a leading provider of research-based indexes and analytics, announced the launch of MSCI Factor ESG Target Indexes. "We are proud to be launching the MSCI Factor ESG Target Indexes today" said Diana Tidd, Head of Index at MSCI. "MSCI is seen as a thought leader in ESG and Factor Investing, and this new suite of indexes helps our clients integrate ESG while still focusing on the benefits of Factor Investing. We work closely with our clients to bring index solutions to market".

(http://www.investopedia.com/terms/m/msci.asp)
\end{abstract}

\title{
4. CSR and Stock Markets
}

The commitment of companies towards sustainable value creation should be recognisable on capital markets and rewarded by shareholders changing traditional market relations.

Long-term oriented companies and investors are vigilant about aligning communications with long-term performance metrics and finding appropriate ways to support an amplified voice for long-term investors (CVSG, 2007). When investors do not have complete and transparent information, the risk of speculative actions is high.

Regular and ongoing dialogue with shareholders is critical for developing and maintaining effective investor relations, understanding the views of shareholders and helping them understand the view of the board (Business Roundtable, 2016): high sustainability companies are significantly more likely to attract dedicated rather than transient investors (Eccles et al., 2014). For this reason, the investor relations (IR) function assumes a critical role (Rodrigues \& Galdi, 2017). IR activities decrease the risk associated with information asymmetry and market abuse (Agarwal et al., 2015), improve the company's visibility and reputation so that the company's shareholder base is widened (Bushee \& Miller, 2012), and increase accuracy in analysts' forecast, reducing the cost of capital and increasing share price (Brennan \& Tamarowsky, 2000).

IR function is the official link between company and investors in the global financial community (Marston, 1996, Dolphin, 2004), providing information and maintaining a dialogue with shareholders. Nowadays the IR function not only covers activities such as information disclosure, coordinating meetings with shareholders and analysts, and evaluating market responses to corporate performance, but it aims to create a long-term interaction with current and potential stakeholders in the capital market. Investor relations may play a role in determining the corporate image orienting the investors' choices, as happens in the products markets for consumers. Furthermore, the fulfilment of Directive 2014/95/UE concerning non-financial and diversity information requires companies to expand the traditional competencies of the IR function, or to establish specialised ESG investor relations function, from the financial year starting in 2017. 
The way companies create consensus on sustainable strategies consists of an effective accountability that promotes content that better complies with the stakeholders' cognitive and evaluative expectations, inducing a gradual change in external reporting, also with the aim of developing transparent models with international value (Salvioni \& Bosetti, 2014).

The attention from international institutions, national regulators and self-regulatory codes of conduct towards implementing widely accepted and high-quality governance principles and standards tends to promote and ensure the overall fairness of transactions. This situation favours the movement of investors from one market to another because of considerations about economic convenience and risk diversification. This situation increases the competition between companies for the acquisition of resources on global markets and it produces a gradual path for formal convergence that means sharing worldwide high quality standards of corporate governance.

In this market's dynamism, the share price, in spite of its limits, endures as the most common metric investors use to capture the entire spectrum of corporate social performance value (positive to negative) across all stakeholders because of its availability and comparability (Peloza, 2009). For this reason, with the diffusion of the concept of social responsibility, the stock exchanges have an important role in promoting CSR through standards of social involvement and tools for appreciating the social performance, in addition to the economic performance, of listed companies (Matei \& Cibotariu, 2011).

Adopting socially responsible behaviours can have a significant and measurable impact on key financial value drivers on the market leading banks, funding institutions and capital providers to seek information on companies' environmental and social performance, as they acknowledge the importance of creating sustainable value and the contribution that CSR provides towards reducing business risk.

Public disclosures on corporate social integrated thinking and performance are utilised by analysts to benchmark historic performance, to establish connections between financial and non-financial parameters and to evaluate trends. Several stock exchanges and indices have been set up to work exclusively on establishing these connections.

Since the end of the last century, the number of indexes aimed at describing the relationship between the economic situation of enterprises and their orientation towards CSR has increased. These indices are developed to establish a benchmark for socially responsible companies and they are a useful reference for investors who consider aspects of ESG in their investment decisions. Thus, for example, in 1999 Dow Jones started publishing the Sustainability Index (SI), a year after the Calvert fund adopted the CSR index, while in 2001 FTSE began publishing the FTSE4Good Sustainability Indicator.

The origin and the development of Socially Responsible Investment (SRI) stock indexes are related to the weakened ability of shareholders to monitor the CSR standards by just using corporate communication. Ethical investments constitute an investment vehicle, which reflects investors' values regarding the impact and conduct of business activities (Williams, 1999; Gardiner et al., 2003; Lo \& Sheu, 2007).

The SRI stock indexes (such as the DJSI family and FTSE4GOOD series) signal compliance with satisfactory CSR standards to stakeholders, encouraging investors 
to select such companies. Furthermore, since SRI performance is not systematically inferior to that of other funds in the long-term, these stock indexes may play a role in providing incentives towards continuous upgrading of sustainability standards (Consolandi et al., 2009; Ziegler, 2009).

In recent years, SRI funds have grown significantly. In fact, inclusion in a sustainability index is an expression of the level of corporate sustainability performance (Consolandi et al., 2009): the inclusion (or deletion from) in such an index is a strong signal for investors about an increase (or decline) in a company's sustainability performance relative to its competitors (Lackmann et al., 2011).

Stock markets have been increasingly reliant on a twofold influence. First, the increasing interest of investment funds for CSR portfolios raises the interest rates for companies adhering to sustainability indices. Furthermore, the growing interest of investors in creating sustainable value promotes the diffusion of socially responsible companies to be included in sustainability indices.

More recently, the need to create a dedicated market to promote the transactions between socially responsible companies and investors who believe that value creation in the long-run is more profitable than speculative actions in the short term has led to the birth of Social Stock Exchanges (SSEs),

The SSEs (such as the South African Social Stock Exchange, the Social Stock Exchange in London, the Impact Exchange in Singapore, and the Social Venture Connection in Canada) propose an innovative financial model, which enables investors to take better decisions, considering a multidimensional concept of corporate performance.

The increasing attention towards the integration between social and economic dimensions confirms that social responsibility is a topic of interest not only for companies, but also for stock exchanges, market authorities and investors. In this sense, we can talk about a concept of CSR that cannot be limited to the companies but that integrates many actors and market relations.

\section{Emerging Issues}

The role of firms in society has changed with the emergence of the new concepts of integrated social responsibility and the effectiveness of relations with all of the company's stakeholders. This has led to a review of the governance approach, according to a logic focused on enhancing the close relationship between competitive, economic, and socio-environmental success, the progressive enhancement of close relationships between financial and non-financial performances and the establishment of the concept of sustainable value creation.

The diffusion of CSR and sustainability principles, together with spreading globalisation, tends to gradually reduce the differences in corporate governance approaches worldwide, promoting a review of corporate performances and the critical factors for competitive success. In fact, the fall of barriers between markets and capital flows is increasing the choices for investors and the belief that the orientation towards sustainable value may be a significant factor in the investment's risk reduction.

The creation of sustainable value expresses a long-term management orientation, based on the progressive improvement of stakeholder relations and the associated 
environmental impacts referring to cohesion and consensus, market opportunities, strengthened reputation and image, a more secure and motivating work environment, improvements in productivity and competitiveness, and more efficient management of natural resources. As a result, it reduces risk and increases company stability and resilience.

Integrated CSR does not mean that value creation for shareholders and their adequate remuneration are less important. Business decisions always require feasibility and economic convenience, but the effective and fair integration between economic and socio-environmental responsibilities enhances the close interdependence between shareholders and stakeholder view, ensuring the company's long-term competitive advantage. Financial analysts and investors have also become increasingly aware of this.

The establishment and the development of stable relations with investors are requirements for corporate decision-making processes that prioritise the creation of greater value in the future instead of maximising immediate profits, when a trade-off between long and short term exists. The disclosure of sustainability information by the company is the main way to nurture and influence these relations.

Investors who understand the importance and the greater guarantees offered by socially responsible firms in terms of financial risk reduction make their own investment decisions based on remuneration and longer-term capitalisation expectations. To make this happen, companies need to be transparent and adopt integrated communication processes where the financial dimension is linked to the non-financial one.

The ability of listed companies to attract consensus and resources in the stock market and to develop stable relationships with investors is also influenced by the transparency of behaviours and reports. Companies will be expected to be transparent not only about their performance along the triple bottom line, but also about the financial risks and opportunities they deal with and the probable effects on the business's value creation, in both the short and long term.

Over the years, an increasing number of listed companies include non-financial information in their annual financial reports. Some countries seem to share the concept of integrated financial and non-financial reporting and in many cases the law or stock exchange regulations promote this reporting.

Furthermore, the inclusion in a SRI fund, such as the listing in a SSE, is often seen by investors as evidence of high sustainability corporate performance. At the same time, the increasing investments in CSR portfolios lead companies to be more interested in belonging to such indexes, activating a virtuous circle that promotes an increase in the level of corporate sustainability with benefits for the community and the national economy. In other words, the evaluation of the CSR performance of a firm could be considered a useful criterion for asset allocation: the demand of stocks characterized by high CSR standards would sustain their value, and this would provide incentives to managers to further be committed to sustainability. From an investors' perspective, this leads to an increased scrutiny regarding non-financial corporate performance (Consolandi et al., 2009).

Finally, it should be emphasized that CSR should not only be interpreted as a factor promoting the corporate image, but it must permeate the management approach and involve all of the company's internal and external relations. The concept of global responsibility engages all the company' levels from board, which can be the change 
agent (Maritz et al., 2011) able to maintain a constant dialogue with stakeholders ensuring the dynamic CSR matters are integrated into corporate objectives for long term value creation, to organisation committed to business operations. With regard to external relations in financial markets, integrated responsibility refers to the involvement of different types of investors, understanding their expectations and balancing short and long-term value creation in their interests and in the interest of the company.

Becoming a sustainable company involves a conscious and continuing effort in the equilibrium between contrasting stakeholders' expectations in the attempt to optimise value creation for everyone. The corporate choice to act in this way is really a cultural matter that needs to be planned and adequately managed according to the following ongoing steps that influence each other (Eccles et al., 2012). The first stage involves reconsidering the leadership commitment, to be sure that the top-level leaders are able to incorporate CSR into the core of business, and strengthening the external engagement, also collaborating with other companies and organisations to advance corporate goals, emphasising global value chains (Zucchella, 2007). The second stage involves codifying the new corporate identity by engaging employees and projecting mechanisms to achieve and monitor the CSR goals.

Therefore integrated CSR calls for a new governance model geared towards systematic, coordinated, effective and efficient implementation of a sustainable approach aimed at giving value to the culture of ethics and the global responsibility at the board, organisation and company network level. In this context, national and international institutions, governments, investors and communities play a crucial role in paying close attention to CSR issues and sustainability matters, encouraging the cultural change companies need.

\section{Bibliography}

Agarwal, V., Taffler, R. J., Bellotti, X., \& Nash, E. A. (2015). Investor relations, information asymmetry and market value, Accounting and Business Research, 46 (1), 31-50. http://dx.doi.org/10.1080/00014788.2015.1025254

Aras, G., \& Crowter, D. (2008). Governance and sustainability: An investigation into the relationship between corporate governance and corporate sustainability, Management Decisions, 46, 433-448.

Bosetti, L. (2015). Social networks and stakeholder engagement. Evidence from Global Compact LEAD participants, Journal of Strategic International Studies, 10, 44-56.

Brennan, M. J., \& Tamarowski, C. (2000). Investor relations, liquidity, and stock prices. Journal of Applied Corporate Finance, 12 (4), 26-37.

Brondoni S. M. (2003). Network Culture, Performance and Corporate Responsibility, Symphonya. Emerging Issues in Management (symphonya.unimib.it), 1, 8-24.

http://dx.doi.org/10.4468/2003.1.02brondoni

Brondoni S. M. (2010). Intangibles, Global Networks \& Corporate Social Responsibility, Symphonya. Emerging Issues in Management (symphonya.unimib.it), 2, 6-24.

http://dx.doi.org/10.4468/2010.2.02brondoni

Brondoni, S. M. (2014). Ouverture de 'Global Networks and Sustainable Development, Symphonya. Emerging Issues in Management, 1, 1-9.

http://dx.doi.org/10.4468/2014.1.01ouverture

Bushee, B., \& Miller, G. (2012). Investor relations, firm visibility, and investor following. Accounting Review, 87 (3), 867-897. 
Business Roundtable (2016). Principles of Corporate Governance, Business Roundtable, August.

Carroll, A. B. (1999). Corporate social responsibility: Evolution of a definitional construct. Business Society, 38, 268-295.

Consolandi, C., Jaiswal-Dale A., Poggiani, E., \& Vercelli, A. (2009). Global Standards and Ethical Stock Indexes: The Case of the Dow Jones Sustainability Stoxx Index, Journal of Business Ethics, 87, 185-197

http://dx.doi.org/10.1007/s10551-008-9793-1

CVSG - The Aspen Institute's Corporate Values Strategy Group (2007). Long-term value creation: Guiding principles for corporations and investors. The Aspen Institute.

Dahlsrud, A. (2008). How corporate social responsibility is defined: An analysis of 37 definitions. Corporate Social Responsibility \& Environmental Management, 15, 1-13.

Dolphin, R. R. (2004). The strategic role of investor relations. Corporate Communications: An International Journal, 9 (1), 25-42. https://doi.org/10.1108/13563280410516474

Eccles, R., Kathleen M. P., \& Serafeim G. (2012). How to become a sustainable company, MIT Sloan Management Review, 53 (4), 43-50.

Eccles, R., Ioannou, I., \& Serafeim, G. (2014). The impact of corporate sustainability on organizational processes and performance, Management Science, 60, 2835-2857.

Freeman, R. E., Wicks, A., Harrison, J., Parmar, B., \& De Colle, S. (2010). Stakeholder Theory: The State of The Art. Cambridge University Press.

Gardiner, L., Rubbens, C., \& Bonfiglioli, E. (2003). Big Business, Big Responsibilities, Corporate Governance, 3, 67-77.

Goedhart, M., Koller, T., \& Wessels, D. (2015). The real business of business, McKinsey on Finance, 53, Winter.

Harrison, J., Freeman, R. E., \& Cavalcanti Sá de Abreu, M. (2015). Stakeholder Theory As an Ethical Approach to Effective Management: applying the theory to multiple contexts, Revista Brasileira de Gestão de Negócios. Review of business management, 17 (55) 858-869.

https://doi.org/10.7819/rbgn.v17i55.2647.

Hillman, A. J., \& Keim, G. D. (2001). Shareholder value, stakeholder management, and social issues: what's the bottom line? Strategic Management Journal, 22, 125-140.

Lackmann, J., Jürgen, E., \& Stich, M. (2011). Market Reaction to Increased Reliability of Sustainability Information, Journal of Business Ethics, 107 (2), 111-128.

Lambin, J. J. (2014). Rethinking the Market Economy, Symphonya. Emerging Issues in Management (symphonya.unimib.it), 2, 4-15.

http://dx.doi.org/10.4468/2014.2.021ambin

Lo, S., \& Sheu, H. (2007). Is Corporate Sustainability a Value-Increasing Strategy for Business?, Corporate Governance. An International Review, 15(2), 345-358.

Maritz, R., Pretorius, M., \& Plant, K. (2011), Exploring the Interface Between Strategy-Making and Responsible Leadership, Journal of Business Ethics, 98, 101-113.

Marston, C. (1996). The organization of the investor relations function by large UK quoted companies. Omega, 24 (4), 477-488.

Matei, M. \& Cibotariu, I. S. (2011). Considerations regarding the social responsibility of stock market's actors, Petroleum-Gas University of Ploiesti Bulletin. Economic Science Series, 85-95.

NACD - National Association of Corporate Directors (2014). Director's Handbook on Oversight of Corporate Sustainability Activities; NACD Library: Washington, DC, USA.

Peloza, J. (2009). The Challenge of Measuring Financial Impacts From Investments in Corporate Social Performance, Journal of Management, 35 (6), 1518-1541.

https://doi.org/ 10.1177/0149206309335188

Porter, M. E., \& Kramer, M. R. (2006). Strategy Society. The link between competitive advantage and CSR, Harvard Business Review, 84, 78-92. 
Porter, M. E., \& Kramer, M. R. (2011). Creating shared value: How to reinvent capitalism-And unleash a wave of innovation and growth, Harvard Business Review, 89, 62-77.

Rodrigues, S. S., \& Galdi, F. C. (2017). Investor relations and information asymmetry, Revista Contabilidade \& Finanças, 1-16. http://dx.doi.org/10.1590/1808-057x201703630

Salvioni D. M. (2010). Intangible Assets and Internal Controls in Global Companies, Symphonya. Emerging Issues in Management (symphonya.unimib.it), 1, 39-51. https://doi.org/10.4468/2010.2.04salvioni.

Salvioni D. M., \& Astori R. (2013). Sustainable Development and Global Responsibility in Corporate Governance, Symphonya. Emerging Issues in Management (symphonya.unimib.it), 1, 1-25. https://doi.org/10.4468/2013.1.03salvioni.astori

Salvioni, D. M., Astori R., \& Cassano R. (2014), Corporate Sustainability and Ethical Codes Effectiveness, Journal of Modern Accounting and Auditing, 10 (9), 969-982.

Salvioni D. M. \& Gennari, F. (2014). Corporate governance, sustainability and capital markets orientation, International Journal of Management and Sustainability, 3(8), 469-483.

Salvioni D. M. \& Bosetti, L. (2014) Sustainable Development and Corporate Communication in Global Markets, Symphonya. Emerging Issues in Management (symphonya.unimib.it), 1, 1-19. http://dx.doi.org/10.4468/2014.1.03salvioni.bosetti

Salvioni D. M. \& Gennari, F. (2016). Corporate Governance, ownership and sustainability, Corporate Ownership and Control, 13 (2), 606-614.

http://dx.doi.org/10.22495/cocv13i2c3p9

Salvioni D. M., Gennari F., \& Bosetti L. (a) (2016). Sustainability and Convergence: The Future of Corporate Governance Systems?, Sustainability, 8, 1203, 1-25.

http://dx.doi.org/10.3390/su8111203

Salvioni, D. M., Franzoni, S., \& Gennari, F. (b) (2016). Corporate governance systems and sustainability: CSR as a factor of convergence between outsider and insider systems, Corporate Ownership and Control,14(1), 139-150.

Schaltegger, S., Hörisch, J., \& Freeman, R. E. (2017). Business Cases for Sustainability: A Stakeholder Theory Perspective, Organization \& Environment, 1-22, in press.

http://dx.doi.org/10.1177/1086026617722882

Tonello, M. (2010). Sustainability in the Boardroom. The Conference Board Director NotesWeb Site. Available online: https://www.conference-board.org/retrievefile.cfm?filename=DN-00810.pdftype $=$ subsite

Van Marrewijk, M., \& Were, M. (2003). Multiple Levels of Corporate Sustainability, Journal of Buisness Ethics, 44, 107-119.

Williams, S. (1999). UK Ethical Investment: a coming of age, Journal of Investing, 8, 58-75.

Winston, B. E., \& Patterson. K. (2006). An integrative definition of leadership, International Journal of Leadership Studies, 1, 6-66.

Ziegler, A. (2009). Is it beneficial to be included in a Sustainability Stock Index? A panel data study for European firms, CCRS Working Paper Series, n. 04/09.

Zucchella, A. (2007). Network Social Responsibility, Symphonya. Emerging Issues in Management (symphonya.unimib.it), 2, 64-71.

http://dx.doi.org/10.4468/2007.2.07zucchella 